\title{
Isolation and characterization of high exopolysaccharide-producing Weissella confusa VP30 from young children's feces
}

\author{
Hui Jin' ${ }^{1}$, Yunju Jeong ${ }^{1,2}$, Sang-Ho Yoo ${ }^{3}$, Tony V. Johnston ${ }^{4}$, Seockmo Ku ${ }^{4^{*}}$ (I) and Geun Eog Ji 1,2*
}

\begin{abstract}
Background: Lactic acid bacteria $(\mathrm{LAB})$ are known to have a significant ability to colonize the human intestinal tract and adhere to the surface of intestinal epithelial cells. Among the various lactic acid bacteria, exopolysaccharide (EPS) producing strains are known to provide a variety of health benefits for their hosts (e.g. anti-inflammatory, antioxidant, antitumor and stress tolerant effects). Recently, EPSs and EPS-producing lactic acid cultures have gained interest within the food industry and are playing important roles as biothickeners and texturizing agents due to their hydrocolloidal nature. In this study, 156 lactic acid bacterial strains isolated from fecal samples of healthy young children were screened and evaluated for active EPS-production capability.

Results: Among the various human origin lactic acid flora isolated, Weissella confusa VP30 showed the highest EPS productivity and its EPS producing properties were characterized under various cultural conditions in this research. To document the safety of W. confusa VP30, antibiotic resistance, hemolytic, and ammonia production properties were evaluated in addition. No significant negative results were observed. The maximum EPS production by $W$. confusa VP30 was $59.99 \pm 0.91 \mathrm{~g} / \mathrm{l}$ after $48 \mathrm{~h}$ of cultivation in media containing $10 \%$ sucrose, far exceeding EPS production by other bacterial strains reported elsewhere. Based on gel permeation chromatography (GPC), the molecular weight of EPS produced by W. confusa VP30 was $3.8 \times 10^{6} \mathrm{Da}$. Structural analysis of the released EPS fraction by ${ }^{13} \mathrm{C}$ and ${ }^{1} \mathrm{H}$ nuclear magnetic resonance (NMR) spectroscopy revealed that $W$. confusa VP30 can produce dextran with glucose units linked with $96.5 \%$ a $(1 \rightarrow 6)$ glycosidic bonds and $3.5 \%$ a $(1 \rightarrow 3)$ branches.
\end{abstract}

Conclusion: The high EPS production capability and safety of W. confusa VP30 justify food industry consideration of this cell strain for further evaluation and potential industrial use.

Keywords: Exopolysaccharide, Weissella confusa, Dextran, Lactic acid bacteria, Safety, Structure

\section{Introduction}

Numerous LAB genera, including Carnobacterium, Enterococcus, Lactobacillus, Lactococcus, Leuconostoc, Oenococcus, Pediococcus, Streptococcus, Tetragenococcus, Vagococcus and Weissella sp. have been isolated from a variety of human, animal, plant and environmental

\footnotetext{
*Correspondence: seockmo.ku@mtsu.edu; geji@snu.ac.kr

1 Department of Food and Nutrition, Research Institute of Human Ecology, Seoul National University, Seoul 08826, South Korea

${ }^{4}$ Fermentation Science Program, School of Agriculture, College of Basic and Applied Sciences, Middle Tennessee State University, Murfreesboro, TN 37132, USA

Full list of author information is available at the end of the article
}

sources and widely utilized for processed food production [1-4]. According to recent industry analysis reports $[5,6]$, the global LAB and probiotics market is characterized by three applications and/or end-uses: (i) probiotics in foods and beverages [e.g. cereal, dry, dairy, non-dairy, baked food and fermented meat products], (ii) probiotic dietary supplements [e.g. nutraceuticals, single cell protein, specialty nutrients, infant formula], and (iii) animal feed probiotics [e.g. substitutes of antibiotic-based growth stimulants]. According to Global Market Insights [7], the US and EU markets were estimated at over USD 1.8 billion and 630 million, respectively, in 2017. This three-part market of significant value is projected to 
grow even further due to increased consumer interest in health and expanding consumer income. An increasing number of food and feed companies are therefore trying to utilize $\mathrm{LAB}$ in their products to meet customer demand, improve product quality, and diversify their product lines [8].

Among LAB strains, human origin LAB strains have shown high resistance to gastric juice and bile as well as high survival rates in the gastrointestinal tract, due to their ability to adhere to the surface of intestinal epithelial cells $[8,9]$. Multiple researchers have demonstrated the diverse biofunctionalities (e.g. anti-allergic effects, anticancer properties, bacteriocin production, high transmission rates and high adherence ability) of human origin $\mathrm{LAB}$ and their metabolic substances through in vitro and in vivo experiments [10-14]. Due to the verified safety and functional effects of human origin $\mathrm{LAB}$, these special LAB have been widely examined and applied to foods and livestock feeds as supplements, resulting in steadily increasing market demand $[5,6]$. Therefore, the isolation of novel functional human origin intestinal bacteria and characterization of their bioactive molecules are important for the production of new value-added products [8]. The screening of novel microorganisms and characterization of their metabolites is regarded as the first step in their utilization as probiotics and drugs, as well as for metabolic engineering [15-17].

Among the bioactive molecules produced by LAB, there is growing demand for EPSs, which are used as biobased polymers [18]. EPS has been widely studied for its economic importance in food processing and beneficial effects. EPS produced by LAB can act as a viscosifier and/or emulsifying agent and play an important role in the processing of yogurt, cheese, and other fermented foods as a stabilizer [19]. Multiple groups have reported that EPS from LAB has significant biofunctional properties and its functionality varies depending on structure and the bacterial strain which produced it. For example, EPS derived from Lactobacillus rhamnosus KL37 has been shown to suppress active arthritis by the inhibition of the production of arthritogenic antibodies [20]. According to London et al. [21], $\beta$-glucan enriched EPS from Lactobacillus paracasei NFBC 338 showed modulatory effects on lipid metabolism. EPS produced by Streptococcus thermophilus ST10 and Weissella cibaria GA44 exhibited physical defense functionality that strengthens the tight junction between human intestinal cells [22], and antioxidant effects [23], respectively. Despite these promising food applications and biofunctionalities, EPS is not yet widely utilized by food processors as a food additive, mainly due to low production rates by LAB [24]. Therefore, screening for novel LAB with high EPS production rates is justified.
In this work, high EPS producing LAB strains with potential food processing applications were isolated from young children's fecal samples and characterized. One hundred fifty-six human origin LAB strains were screened. All 156 LAB samples were inoculated and cultured in seven modified de Man, Rogosa, and Sharpe (MRS) agar (Becton, Dickinson, and Company) medias, each with a different carbon source. The amount of EPS produced from each of the 1248 different groups was qualitatively and/or quantitatively analyzed. Based on our results, the highest EPS-producing LAB (Weissella confusa VP30) and its key carbon source (sucrose) for high EPS production were determined. Further structural characterization using NMR analysis allowed us to elucidate the conformation of EPS from W. confusa VP30. This strain is also safe to use as an edible LAB from a food safety standpoint, according to our previous research [25].

\section{Materials and methods}

Sampling and isolation of LAB from young children's feces

Using a study protocol approved by the Seoul National

University Institutional Review Board (IRB No. 1702/002-013), fresh fecal samples were collected from five young children between 1 and 6 years old for this study. The fecal samples were transported to the laboratory at $4{ }^{\circ} \mathrm{C}$ for LAB isolation in a laminar flow hood. One gram samples from each feces collected was mixed with a sterilized phosphate buffered saline solution (PBS; $137 \mathrm{mM} \mathrm{NaCl}, 2.7 \mathrm{mM} \mathrm{KCl}, 4.3 \mathrm{mM} \mathrm{Na} 2 \mathrm{HPO}_{4}, 1.47 \mathrm{mM}$ $\mathrm{KH}_{2} \mathrm{PO}_{4}, \mathrm{pH}$ 7.4) [26]. After serial dilution, the suspension of each sample was plated on Lactobacillus Selection (LBS) (Difco) agar or transgalctosylated oligiosaccharide (TOS-MUP) (MB cell) agar and incubated under anaerobic conditions at $37{ }^{\circ} \mathrm{C}$ for $48 \mathrm{~h}$ for LAB isolation. LBS $[27,28]$ and TOS-MUP $[29,30]$ were used to screen $L a c$ tobacillus and Bifidobacterium spp. from fecal samples, respectively.

One hundred fifty-six morphologically different microbial colonies were randomly collected and the selected colonies were Gram stained and morphologically evaluated using an optical microscope. The isolated LAB strains were then cultured in modified MRS media according to our previous studies [9, 26, 31, 32]. In brief, all 156 LAB samples were inoculated and cultured in seven types of modified MRS agar media with different carbon sources $[10 \%(w / v)$ of glucose (Sigma), sucrose (Sigma), galactose (Sigma), lactose (Difco), fructose (Sigma), raffinose (Sigma) and maltose (Sigma)] and commercially available MRS media (1248 total samples).

According to Ruas-Madiedo and De Los Reyes-Gavilán [33], mucinous strands can be observed visually when sterilized inoculation loop are contacted with microbial 
colonies that produce EPS as a metabolite. Therefore, we conducted an initial screening using a sterilized inoculation loop or sterilized toothpicks to screen for EPS production candidates. From the 1248 samples, the 10 most mucoid and slimy colonies and/or media conditions were selected for further study. 16S rRNA gene sequencing was performed to accurately identify these 10 strains at the molecular level.

\section{Phylogenetic analysis}

The selected microbial isolates were then subjected to phylogenetic analysis. DNA from each isolate was isolated, amplified by PCR, and the $16 \mathrm{~S}$ rRNA genes in the PCR products were sequenced. The PCR primers used were 27F (5'-AGAGTTTGATCMTGGCTC AG- $\left.3^{\prime}\right) / 1492 \mathrm{R} \quad\left(5^{\prime}\right.$-TACGGYTACCTTGTTACGACTT$\left.3^{\prime}\right)$ and the $16 \mathrm{~s}$ rRNA sequencing primer was $785 \mathrm{~F}\left(5^{\prime}-\right.$ GGATTAGATACCCTGGTA-3')/907R (5'-CCGTCA ATTCMTTTRAGTTT-3'). The PCR sequencing step was executed by Macrogen, Inc. (Seoul, Korea), and the full sequence of $16 \mathrm{~S}$ rRNA gene was aligned using the NCBI database, to the species level [34].

\section{Analysis of EPS production properties of $10 \mathrm{LAB}$ strains}

The level of EPS production of $10 \mathrm{LAB}$ strains cultivated in modified MRS broth containing $10 \%(\mathrm{w} / \mathrm{v})$ sucrose instead of glucose was enumerated and compared using our previously published protocol with slight modifications $[9,26,31,32]$. Specifically, cultured bacteria was boiled for $15 \mathrm{~min}$ and treated with $17 \%(\mathrm{v} / \mathrm{v}) 85 \%$ trichloroacetic acid (TCA) (Sigma) $2 \mathrm{~h}$ after cell cultivation for $24 \mathrm{~h}$ at $37^{\circ} \mathrm{C}$. LAB pellets were separated from culture media via centrifugation at $18,000 \times g$ for $25 \mathrm{~min}$ [35]. A $5 \mathrm{ml}$ aliquot of the supernatant was mixed with $25 \mathrm{ml}$ of $95 \%$ ethanol $\left(-20{ }^{\circ} \mathrm{C}\right)$, and incubated at $4{ }^{\circ} \mathrm{C}$ for $16 \mathrm{~h}$. The precipitated EPS was centrifuged at $18,000 \times g$ for $20 \mathrm{~min}$, and the supernatant was discarded. Crude EPS precipitant was collected and mixed with $5 \mathrm{ml}$ of water. Water and crude EPS mixture was dialyzed using a commercially available dialysis bag (12 to $14 \mathrm{kDa}$ ) and DI water at $4{ }^{\circ} \mathrm{C}$ for $48 \mathrm{~h}$. The EPS sample inside each bag was collected and dried in a Speed Vacuum Concentrator (ScanSpeed 40, SCANVAC; LaboGene) at $2000 \mathrm{rpm}$ and $35{ }^{\circ} \mathrm{C}$ for $24 \mathrm{~h}$. The EPSs in the media supernatants were then quantified by the phenol-sulfuric acid method in a microplate format using glucose as the reference standard [35]. EPS yields ranged from $0.12 \pm 0.04$ to $59.99 \pm 0.91 \mathrm{~g} / \mathrm{l}$. The highest EPS-producing LAB strains were selected for further analysis.

\section{Structural analysis}

The monosaccharide composition of EPS was analyzed after hydrolysis. Hydrolysis of EPS (10 mg) was performed with $2 \mathrm{ml}$ of $2 \mathrm{M}$ Trifluoroacetic acid (TFA) in a sealed tube at $110{ }^{\circ} \mathrm{C}$ for $6 \mathrm{~h}$, and the TFA was removed by speed vacuum. The dried hydrolyzed samples were dissolved in distilled water $(1 \mathrm{ml})$ and analyzed by HPLC (Thermo Fisher Scientific) [36]. The HPLC system consisted of an Ultimate 3000 pump with an auto sampler and Shodex RI-101 (Shodex, Japan) detector. Sugars were analyzed by sugar-pak (Waters, $300 * 6.5 \mathrm{~mm}$, USA) column maintained at $70{ }^{\circ} \mathrm{C}$. Ten microliter samples were injected and eluted with triple distilled water at a flow rate of $0.5 \mathrm{ml} / \mathrm{min}$. GPC and NMR analyses of the EPS produced was performed by the National Instrumentation Center for Environmental Management (NICEM) at Seoul National University Molar mass was determined by GPC [Thermo Dionex HPLC, Ultimate 3000 RI System (Thermo Fisher Scientific)]. A calibration curve was established with Pullulan standards of $\mathrm{Mw} 0.342,10,113$, 393, $805 \mathrm{kDa}$ dissolved in water containing $0.1 \mathrm{M}$ sodium azide $\left(\mathrm{NaN}_{3}\right)$. Three columns, Waters Ultrahydrogel 120, Waters Ultrahydrogel 500 and Waters Ultrahydrogel 1000 , with respective exclusion volumes of $5 \times 10^{3}$ and $1 \times 10^{6} \mathrm{Da}$, were connected in series. The injected sample volume was $50 \mu \mathrm{l}$ and the mobile phase was the same sodium azide buffer used to dissolve the sample, flowing at $1 \mathrm{ml} / \mathrm{min}$ at a temperature of $40{ }^{\circ} \mathrm{C}$. NMR analysis was conducted using a High Resolution NMR Spectrometer (AVANCE 600, Bruker, Germany). Briefly, W. confusa VP30 was cultured in mMRS broth with $10 \%$ $(\mathrm{w} / \mathrm{v})$ of sucrose for $24 \mathrm{~h}$ anaerobically. The collected EPS was purified in the manner previously mentioned. $10 \mathrm{mg}$ samples of purified EPS were dissolved in $1 \mathrm{ml}$ of D2O and the process of ${ }^{1} \mathrm{H}$ NMR, ${ }^{13} \mathrm{C}$ NMR and 2D NMR was heteronuclear single-quantum coherence (HSQC), and Heteronuclear Multiple Bond Correlation (HMBC), at $600 \mathrm{MHz}$ at $25^{\circ} \mathrm{C}$.

\section{Safety evaluations of $W$. confusa VP30}

A safety assessment of $W$. confusa VP30 via ammonia production, hemolysis of blood cells and antimicrobial susceptibility analysis was conducted according to previously reported methods [25]. To evaluate the concentration of secreted ammonia, W. confusa VP30 was cultured in Brain Heart infusion (BD Bacto ${ }^{\mathrm{TM}}$ BHI, LOT 8114937), and the cell-free broth supernatants were recovered after centrifugation at $10,000 \times g$ at $4{ }^{\circ} \mathrm{C}$ for $30 \mathrm{~min}$. The BHI was adjusted to $\mathrm{pH} 7$ using $1 \mathrm{~N} \mathrm{NaOH}$ before cell inoculation. As previously mentioned, two types of chemical reagents were prepared. The 1st reagent consisted of $1 \mathrm{~g}$ phenol and $0.005 \mathrm{~g}$ sodium nitroferricyanide dehydrate $\left(\mathrm{Na}_{2}\left[\mathrm{Fe}(\mathrm{CN})_{5} \mathrm{NO}\right] \cdot 2 \mathrm{H}_{2} \mathrm{O}\right)$ dissolved in $100 \mathrm{ml} \mathrm{DI}$ water, and the 2nd reagent consisted of $500 \mathrm{mg} \mathrm{NaOH}$ and $0.04 \mathrm{~g} \mathrm{NaClO}$ dissolved in $100 \mathrm{ml} \mathrm{DI}$ water. Aliquots $(100 \mu \mathrm{l})$ of Solutions 1 and 2 were added to Corning ${ }^{\circledR} 96$ 
well plates (Costar \# 3595, Corning, NY, USA) with $10 \mu \mathrm{l}$ of the cell-free broth supernatants of W. confusa VP30. An ammonia solution (Junsei Chemical, Japan) was used as a control solution. The 96 well plates were incubated in $25^{\circ} \mathrm{C}$ for $1 \mathrm{~h}$, and spectroscopy analysis was conducted at $625 \mathrm{~nm}$. Cell-free BHI broth was used as a negative control and the ammonia concentration was assessed using a standard curve. Three replications of this test were conducted for statistical analysis of ammonia production from W. confusa VP30.

To evaluate microbial hemolytic properties, W. confusa VP30 was anaerobically cultured in BHI agar supplemented with $1.5 \%$ agar, $10 \%$ of sucrose and $5 \%$ horse blood at $37^{\circ} \mathrm{C}$ for 2 days. Listeria ivanovii subsp. ivanovii ATCC 19119, a positive control for hemolysis, was aerobically cultivated in $\mathrm{BHI}$ agar at $37^{\circ} \mathrm{C}$ for 2 days. According to our previous protocol [25], the plate was then observed for the presence of microbial hemolysis by holding the plate to a light source and looking through both sides of the plate. Strains showing blood lysis (transparent region) around the colony were classified as microorganisms having hemolytic ( $\beta$-hemolytic) characteristics. Strains that produced green-hued zones around the colonies ( $\alpha$-hemolysis) or no hemolysis on the blood plates $(\gamma$-hemolysis) were considered non-hemolytic.

Minimum inhibitory concentration (MIC) tests were conducted to evaluate antimicrobial susceptibility [25]. Sixteen antimicrobial agents were used: ampicillin sodium salt (Sigma, Lot\# BCBW1243), carbenicillin disodium salt (Sigma, Lot\# 126M4775V), chloramphenicol (Sigma, Lot\# SLBR8869V), clindamycin hydrochloride (Sigma, Lot\# 021M1533), dicloxacillin sodium salt hydrate (Sigma, Lot\# SZBD263XV), erythromycin (Sigma, Lot\# WXBC4044V), gentamicin sulfate (Sigma, Lot\# SLBP3082V), kanamycin sulfate (Sigma, Lot\# 066M4019V), methicillin sodium salt (Sigma, Lot\# BCBR6817V), metronidazole (Sigma, Lot\# MKBZ3056V), neomycin sulfate (Sigma, Lot\# LRAB3300), phosphomycin disodium salt (Sigma, Lot\# 096M4031V), polymyxin B sulfate salt (Sigma, Lot\# 126M4071V), spectinomycin sulphate (Sigma,Lot\# LRAB3670), streptomycin sulfate salt (Sigma, Lot\# SLBT8451), tetracycline (Sigma, Lot\# 126M4769V), vancomycin hydrochloride (sigma Lot\# LRAB3620). Each of the antibiotic powders were dissolved and diluted in appropriate diluents and filter sterilized prior to addition to LAB susceptibility test medium (LSM) supplemented with cysteine (LSM-Cys) broth medium, composed of $90 \%$ of Iso-Sensitest Broth (IST)(Mbcell Lot\#P2745063MS, Seoul, Korea) and 10\% of MRS(BD Difco $^{\mathrm{TM}}$, Franklin Lakes, NJ, USA) broth medium. Serial dilutions of antimicrobial agents ranging from 1024 to $0.0032 \mu \mathrm{g} / \mathrm{ml}$ were prepared. MIC values for all bacterial isolates were determined by the ISO 10932:2010 broth microdilution procedure [37]. The LSM-Cys broth medium supplemented with $0.03 \%(\mathrm{w} / \mathrm{v})$ L-cysteine $\mathrm{HCl}$ containing antibiotics at different concentrations was used to prepare each well of a microwell plate. The inoculum was adjusted to a turbidity equivalent to 0.16 to 0.2 at $625 \mathrm{~nm}$ as measured by a spectrophotometer (SpectraMax 190 Microplate reader, Molecular Devices). The solution corresponded to approximately $3 \times 10^{8} \mathrm{cfu} / \mathrm{ml}$. Each inoculum was added to a double strength LSM-Cys broth medium at a rate of $0.2 \%$. A $50 \mu \mathrm{l}$ diluted bacterial suspension was added to each well; no negative control well was employed. The microdilution plates were prepared with a series of twofold dilutions of antibiotics. The microdilution plates were incubated at $37^{\circ} \mathrm{C}$ for $48 \mathrm{~h}$ in an anaerobic $\left(5 \% \mathrm{CO}_{2}, 10 \% \mathrm{H}_{2}\right.$ and $\left.85 \% \mathrm{~N}_{2}\right)$ chamber. The MIC was defined as the lowest concentration of antibiotic giving a complete inhibition of visible growth in comparison to an antibiotic-free control well. The experiments were replicated three times.

\section{Statistical analysis}

To evaluate EPS production levels, statistical analysis was performed with one-way ANOVA using SPSS 24.0 at a significance level of $p<0.05$.

\section{Results and discussion}

\section{Selection of high EPS-producing cell strains}

Multiple groups have screened and identified LAB capable of producing EPSs by cell and colony phenotypes in solid medium. This visual cell classification tool has been widely used for many years to identify EPS producing LAB from naturally occurring microbiota as a preselection process. This preselection process has the advantage of being able to screen multiple samples rapidly without special and expensive tools. However, this cell screening process is almost impossible to standardize because colony morphological differences are distinguished via subjective interpretation by the researcher [33]. In addition, some extracellular macromolecules and polymers from LAB might not show significant slime-forming properties and may thus potentially be misidentified as false negatives. According to Rühmann et al. [38], one option to overcome this experimental issue is comparison of colony characteristics (shape, size, pigmentation, etc.) between induced and non-induced EPS production conditions. Since microbial culture conditions and the carbon source of the medium significantly affect EPS productivity and metabolite characteristics [39], effective substrate dependent EPS-producing LAB screening can be achieved by culturing selected cell strains on media supplemented with various carbon sources. 
In this work, a total of 156 morphologically different human origin LAB cell colonies were screened from five young (1 to 6 years old) children's fecal samples using selective media (i.e. LBS or TOS-MUP) as a prescreening step. All 156 LAB colonies were subcultured in commercially available MRS, and pure microbial cultures were obtained by streaking on agar plates. The pure LAB cultures were then cultivated in seven kinds of mMRS media containing one of seven sugars (glucose, sucrose, galactose, lactose, fructose, raffinose and maltose) or commercially available MRS plates. Stickiness was visually and qualitatively observed by touching the microbial colonies with a sterilized inoculation loop or sterilized toothpicks. All 156 of the LAB colonies grown in sucrose showed the most sticky and viscous characteristics versus those grown with other carbohydrate sources. From these, 10 putative
EPS-producing LAB candidates were chosen for further study due to their mucoid, slimy, and string-forming appearance. The 16s rRNA of each of these colonies was sequenced and the crude EPS was extracted and obtained by the protocol described by Mendi et al. [35] . Crude EPS solutions from these 10 LAB cultures were used to assess their total carbohydrate content via phenol-sulfuric acid assay. Data comparison with NCBI database sequences for the variable region of the $16 \mathrm{~S}$ rRNA gene to the species level identified eight out of 10 putative EPS-producing LAB as belonging to the genus Lactobacillus and other two to Weissella and Bifidobacterium. The EPS production of each LAB strain is shown in Table 1. W. confusa VP30 (Fig. 1a) produced significantly more EPS than the other LAB strains with significant mucoid appearance (Fig. 1b). In the mMRS broth, the W. confusa VP30 produced $59.99 \pm 0.91 \mathrm{~g} / \mathrm{l}$

Table 1 Overall ranking of isolated strains based on EPS production in mMRS with $10 \%$ sucrose (w/v)

\begin{tabular}{|c|c|c|c|c|c|}
\hline No. & $16 s$ rRNA & Strain & $\begin{array}{l}\text { EPS produced, } \\
\text { mean } \pm S D(g / l)\end{array}$ & Host gender & Host age \\
\hline 1 & Weissella confusa & VP30 & $59.99 \pm 0.91^{\mathrm{A}}$ & Male & 5 \\
\hline 2 & Bifidobacterium longum subsp. longum & JH628 & $0.29 \pm 0.06^{B}$ & Male & 1 \\
\hline 3 & Lactobacillus plantarum & $\mathrm{JH} 43 \mathrm{~A}$ & $0.28 \pm 0.02^{B}$ & Female & 4 \\
\hline 4 & Lactobacillus plantarum & JH102 & $0.26 \pm 0.07^{\mathrm{B}}$ & Male & 3 \\
\hline 5 & Lactobacillus fermentum & JH43B & $0.25 \pm 0.11^{\mathrm{B}}$ & Female & 4 \\
\hline 6 & Lactobacillus paracasei & JH907 & $0.23 \pm 0.02^{B}$ & Female & 3 \\
\hline 7 & Lactobacillus plantarum subsp. plantarum & JH917 & $0.21 \pm 0.04^{\mathrm{B}}$ & Male & 1 \\
\hline 8 & Lactobacillus plantarum & JH639 & $0.21 \pm 0.01^{\mathrm{B}}$ & Female & 4 \\
\hline 9 & Lactobacillus rhamnosus & JH914 & $0.19 \pm 0.04^{\mathrm{B}}$ & Male & 1 \\
\hline 10 & Lactobacillus paracasei & $\mathrm{JH} 124$ & $0.12 \pm 0.04^{c}$ & Female & 4 \\
\hline
\end{tabular}

All microorganisms were anaerobically cultured in glucose-free basal MRS supplemented with $10 \%$ (w/v) sucrose at $37^{\circ} \mathrm{C}$ for $24 \mathrm{~h}$. One-way ANOVA followed by Duncan's post hoc test statistical analyses were performed. EPS produced $\left(\mathrm{g} \mathrm{I}^{-1}\right) \pm \mathrm{SE}$ with different letters (where A B $\left.>\mathrm{C}\right)$ are significantly different at $p<0.05(n=3)$
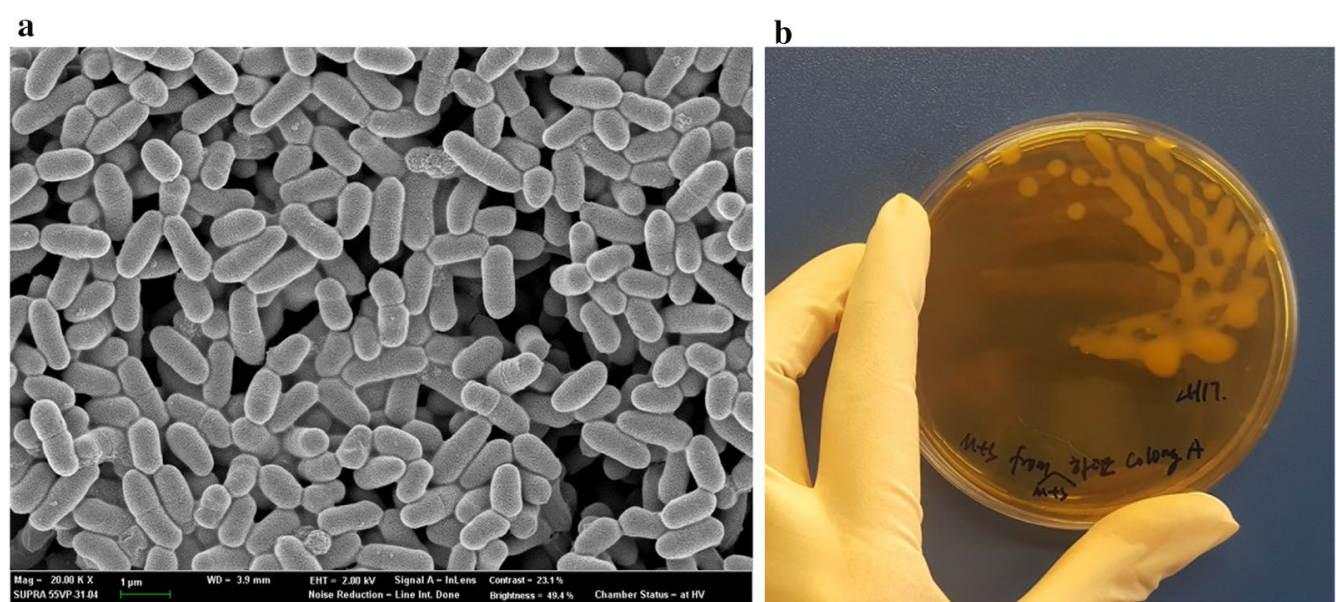

Fig. 1 a Scanning electron microscope images of $W$. confusa VP30 isolated from a fecal sample from a 5 year old boy, and $\mathbf{b}$ Morphological aspects of EPS production by W. confusa VP30 grown under mMRS with $10 \%$ sucrose culture for $24 \mathrm{~h}$ 
of EPS, while the other identified LAB strains produced $<0.3 \mathrm{~g} / \mathrm{l}$ of EPS.

Weissella was originally classified as Leuconostoc or Lactobacillus. However, distinctive biochemical features in Leuconostoc or Lactobacillus were identified by Collins et al. and reclassified as Weissella in 1993 [40]. As a naturally occurring microbiota, Weissella has been widely engaged in spontaneous lactic acid fermentation and coolship alcoholic beverage fermentations [41], and various Weissella strains have recently attracted attention from academia due to their high EPS production ability. Unlike other studies that utilized food-origin bacteria, we isolated and used human-origin strains in this study. The major carbon sources that induce high EPS production varies depending on the microorganism [33]. Sugar transportation pathways, enzyme synthesis metabolism and sugar-nucleotide precursors can be regulated by catabolite repression [33]. In the screening step, all the carbon sources mentioned in the previous study were used. These results show that sucrose is the main carbon source for the production of EPS, which is consistent with previous studies [42, 43]. As shown in Table 2, Weissella spp. have higher EPS production capacity than other LAB strains. However, the EPS production properties of $W$. confusa VP30 in this report are significantly higher than those previously reported.

Table 2 Various LAB culture conditions utilized for EPS quantitative analysis by other groups

\begin{tabular}{|c|c|c|c|c|c|c|c|c|}
\hline Strain & Source & Medium & Type of EPS & $\begin{array}{l}\text { Molecular mass } \\
\text { (Da) }\end{array}$ & $\begin{array}{l}\text { Production } \\
(\mathrm{g} / \mathrm{l})\end{array}$ & Method & Standard & References \\
\hline W. confusa VP30 & $\begin{array}{l}\text { Young children } \\
\text { feces }\end{array}$ & $\begin{array}{l}\text { MRS + } 10 \% \\
\text { sucrose }\end{array}$ & Dextran & $3.8 \times 10^{6}$ & $60.0 \pm 0.9$ & $\begin{array}{l}\text { Phenol-sulfuric } \\
\text { acid method }\end{array}$ & Glucose & This work \\
\hline W. cibaria WC4 & Sourdough & $\begin{array}{l}\text { MRS }+10 \% \\
\quad \text { sucrose } 30{ }^{\circ} \mathrm{C} \\
6 \text { days }\end{array}$ & Glucan & $1.1-1.3 \times 10^{4}$ & $7.9 \pm 0.1$ & $\begin{array}{l}\text { Phenol-sulfuric } \\
\text { method }\end{array}$ & - & {$[46]$} \\
\hline W. cibaria MG1 & Sourdough & $\begin{array}{l}\text { MRS }+10 \% \\
\quad \text { sucrose } 30^{\circ} \mathrm{C} \\
48 \mathrm{~h}\end{array}$ & Dextran & $7.2 \times 10^{8}$ & 36.4 & - & - & [78] \\
\hline $\begin{array}{l}\text { W. confusa } \\
\text { KR780676 }\end{array}$ & Idli batter & $\begin{array}{l}\text { MRS }+2 \% \\
\text { sucrose } 30^{\circ} \mathrm{C} \\
48 \mathrm{~h}\end{array}$ & Galactan & ND & 17.2 & Dry weight & - & [88] \\
\hline W. confusa NH02 & Nham & $\begin{array}{l}\text { MRS }+4 \% \\
\quad \text { sucrose } 37^{\circ} \mathrm{C} \\
12 \mathrm{~h}\end{array}$ & ND & $1.13 \times 10^{6}$ & 18.08 & - & - & {$[48]$} \\
\hline $\begin{array}{l}\text { W. hellenica } \\
\text { SKkimchi3 }\end{array}$ & Kimchi & $\begin{array}{l}\text { MRS + sucrose } \\
20^{\circ} \mathrm{C} 48 \mathrm{~h}\end{array}$ & Glucan & $2.03 \times 10^{5}$ & 5.12 & - & - & [49] \\
\hline W. cibaria 27 & Kimchi & $\begin{array}{l}60 \mathrm{~g} / \mathrm{l} \text { of sucrose } \\
22^{\circ} \mathrm{C} \text { and } \mathrm{pH} \\
6.2 \text { for } 24 \mathrm{~h}\end{array}$ & Glucan & $1.2 \times 10^{7}$ & 24.8 & $\begin{array}{l}\text { Lyophilized dry } \\
\text { weight }\end{array}$ & & [47] \\
\hline $\begin{array}{l}\text { Leu.pseudomes- } \\
\text { enteroides }\end{array}$ & Soybean paste & $\begin{array}{l}5 \% \text { sucrose } 30^{\circ} \mathrm{C} \\
\text { for } 48 \mathrm{~h}\end{array}$ & Glucan & - & 12.5 & $\begin{array}{l}\text { Phenol sulfuric } \\
\text { acid method } \\
\text { [89] }\end{array}$ & & {$[60]$} \\
\hline W. confusa & - & $80 \mathrm{~g} / \mathrm{l}$ of sucrose & - & - & 25.2 & $\begin{array}{c}\text { Freeze drying } \\
\text { dry weight }\end{array}$ & & [90] \\
\hline Leu. citreum B-2 & $\begin{array}{l}\text { Homemade } \\
\text { fermentation } \\
\text { product of } \\
\text { pineapple }\end{array}$ & $75 \mathrm{~g} / \mathrm{l}$ sucrose & Glucan & $3.77 \times 10^{6}$ & 28.3 & $\begin{array}{l}\text { Lyophilized dry } \\
\text { weight }\end{array}$ & & [51] \\
\hline $\begin{array}{l}\text { W. confusa } \\
\text { OF126 }\end{array}$ & Ogi & $\begin{array}{c}24.0 \mathrm{~g} / \mathrm{l} \text { sucrose, } \\
\mathrm{pH}(7.00)\end{array}$ & Glucan & $1.1 \times 10^{6}$ & 3.10 & $\begin{array}{l}\text { Lyophilized dry } \\
\text { weight }\end{array}$ & & [50] \\
\hline $\begin{array}{l}\text { Leu. Mesenter- } \\
\text { oides } 109\end{array}$ & Plant & $\begin{array}{l}20 \mathrm{~g} / \mathrm{l} \text { of fruc- } \\
\text { tose, } 50 \mathrm{~g} / \mathrm{l} \text { of } \\
\text { sucrose }\end{array}$ & Glucan & $1.4 \times 10^{6}$ & 19.0 & $\begin{array}{l}\text { Polymer dry } \\
\text { mass } 42^{\circ} \mathrm{C} \\
48 \mathrm{~h}\end{array}$ & & {$[52]$} \\
\hline W. cibaria & $\begin{array}{l}\text { Fermented } \\
\text { sauropus } \\
\text { androgynus }\end{array}$ & Sucrose & Glucan & - & 6.4 & $\begin{array}{l}\text { Lyophilized dry } \\
\text { weight }\end{array}$ & & {$[45]$} \\
\hline W. sp. PSMS4-4 & Plasom & $\begin{array}{l}5 \% \text { White-sugar } \\
30^{\circ} \mathrm{C}\end{array}$ & Glucan & - & 8.7 & $\begin{array}{l}\text { Phenol sulfuric } \\
\text { acid method } \\
\text { [89] }\end{array}$ & Glucose & [91] \\
\hline
\end{tabular}




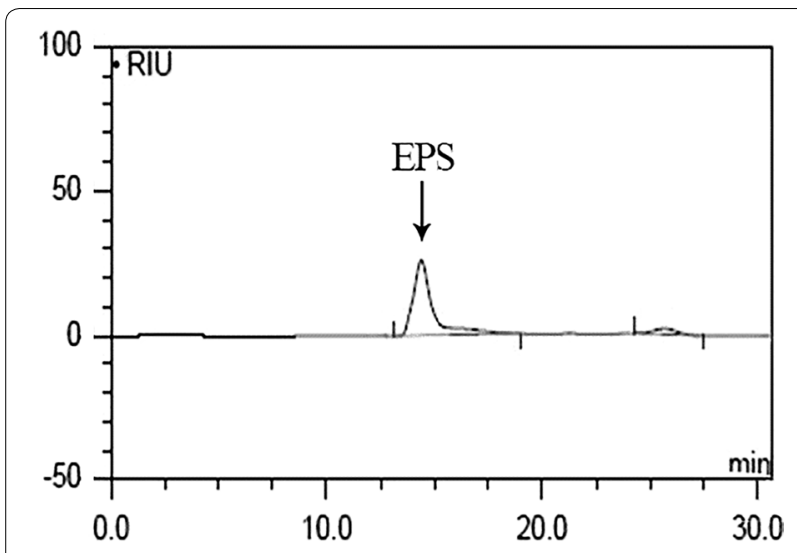

Fig. 2 Elution profile and determination of molecular weight of W. confusa VP30 EPS by gel filtration on Thermo Dionex HPLC with Ultimate 3000 RI System. Pullulan of multiple molecular mass were used as the standard

\section{Evaluation of EPS constituents}

The carbohydrate composition of EPS isolated from W. confusa VP30 was consisted predominantly of glucose. The weight-average molecular weight $(\mathrm{Mw})$ of the EPS was determined by GPC analysis with three columns (i.e. Waters Ultrahydrogel 120, Waters Ultrahydrogel 500 and Waters Ultrahydrogel 1000), where a typical sharp symmetrical peak was observed (Fig. 2) [44, 45]. W. confusa VP30 produced $3.8 \times 10^{6}$ Da EPS which is significantly larger than those from other Weissella spp. (Table 2) [46-52].

The ${ }^{1} \mathrm{H}$ NMR spectrum of the $W$. confusa VP30 produced EPS is shown in Fig. 3a. The peaks were distributed into two regions, upfield of 3.5-4.0 ppm and downfield of $4.9-5.3 \mathrm{ppm}$. This was in agreement with the $1 \mathrm{H}$ NMR spectrum of dextran where the proton signals at $\mathrm{C}-2, \mathrm{C}-3, \mathrm{C}-4, \mathrm{C}-5$, and $\mathrm{C}-6$ were found in the range of
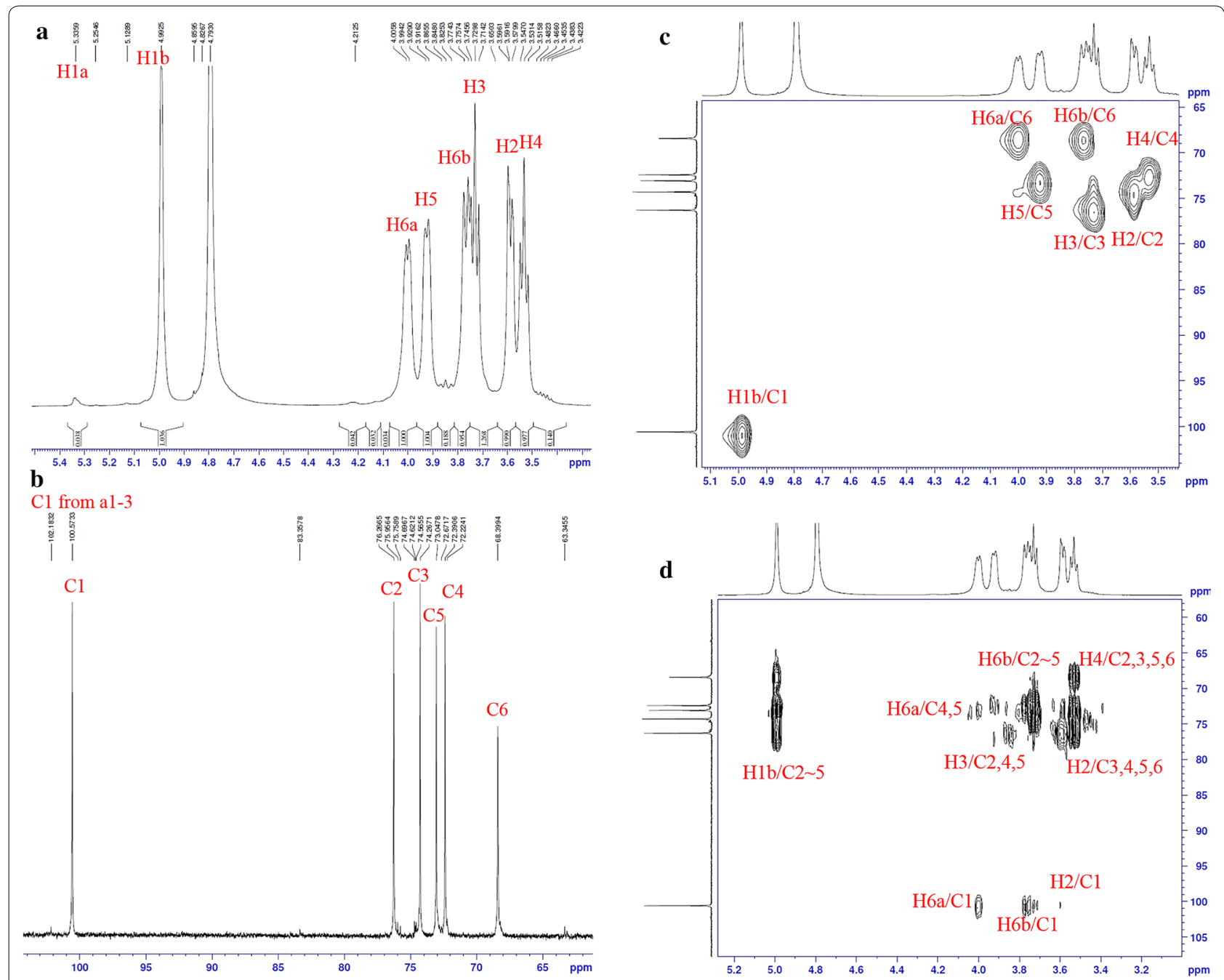

Fig. 3 1D NMR spectrum of purified EPS from W. confusa VP30 in D2O: a ${ }^{1} \mathrm{H}$ NMR (600 MHz); $\mathbf{b}^{13} \mathrm{C} \mathrm{NMR} \mathrm{(150} \mathrm{MHz).} \mathrm{c} \mathrm{HSQC} \mathrm{spectrum;} \mathbf{d}$ HMBC spectrum 
3-4 ppm while C-1 was found in the 4-6 ppm region [47, 53-55]. The chemical structure of EPS should be alpha as the chemical shift is $100.57 / 4.99 \mathrm{ppm}$ for ${ }^{13} \mathrm{C} /{ }^{1} \mathrm{H}$ while 5.3-5.7 ppm for ${ }^{1} \mathrm{H}$ and 103-106 ppm for ${ }^{13} \mathrm{C}$ belongs to beta form [47]. From the spectrum, two peaks of anomeric protons were observed. The high intensity peak at $4.99 \mathrm{ppm}$ was referred to as the anomeric proton of the $\alpha(1 \rightarrow 6)$ linkages in the main chain $[47,56]$, whereas the low intensity peak at $5.33 \mathrm{ppm}$ represented the anomeric proton of the $\alpha(1 \rightarrow 3)$ branch linkages [56]. A ratio of 96.5:3.5 was obtained from the integration of the relative intensity of the signal at 4.99 and $5.33 \mathrm{ppm}$. This result suggests that the dextran was composed of $96.5 \%$ $\alpha(1 \rightarrow 6)$ linkages in the main chain and $2.6 \% \alpha(1 \rightarrow 3)$ branch linkages. The ${ }^{13} \mathrm{C}$ NMR spectrum revealed six peaks appearing between 68 and 100 ppm (Fig. 3b). In previous studies, anomeric carbon signals were generally found downfield, in the region of 95-105 ppm. The signals in 95-101 ppm were related to a-anomeric carbons, and the signals in 101-105 ppm were due to $\beta$-anomeric carbons in ${ }^{13} \mathrm{C}$ NMR spectra, which corresponded with the ${ }^{1} \mathrm{H}$ NMR spectra [57]. Carbon signals at $\mathrm{C}-2, \mathrm{C}-3, \mathrm{C}-4$, and $\mathrm{C}-5$ were found in the range of 70-75 ppm, while C- 6 was found in the upfield region at about $60 \mathrm{ppm}$ [58]. Moreover, dextran branch linkage signals were found around 77-85 ppm [59]. In this study, the signal at $100.57 \mathrm{ppm}$ was clearly due to the anomeric carbon C-1, while the signal at 68.39 ppm was due to C-6. This peak was also observed at a lower intensity compared to the other peaks since some parts of the $\alpha$ $(1 \rightarrow 6)$ linkages had been replaced by $\alpha(1 \rightarrow 3)$ branches. However, the signal referring to branch linkages around 77-85 ppm was absent due to the small amount of $\alpha$ $(1 \rightarrow 3)$ linkages. To assign the signals at $72.39,73.04$, 74.26 , and $76.26 \mathrm{ppm}$, the data from 2D NMR were also analyzed. $\mathrm{HSQC}(\mathrm{c})$ and $\mathrm{HMBC}(\mathrm{d})$, which provided the correlation between ${ }^{1} \mathrm{H}$ and $13 \mathrm{C}$ direct bond and two bonds, respectively, were used to confirm the structure of the polysaccharide (Fig. 3c, d). From the HSQC spectrum, seven protons in the glucose residue were found to correlate. The correlation of $1 \mathrm{H}$ at $4.99 \mathrm{ppm}$ and ${ }^{13} \mathrm{C}$ at $100.57 \mathrm{ppm}$ confirmed the presence of $\alpha(1 \rightarrow 6)$ glycosidic bond. Other assignments from the HSQC and $\mathrm{HMBC}$ analysis of each position are presented in Table 3. The NMR results are similar to dextran produced by $W$. confusa R003 [56] and this HSQC, and HMBC similarities confirmed that the dextran was composed of glucose units linked with $96.5 \% \alpha(1 \rightarrow 6)$ glycosidic bonds and $3.5 \% \alpha(1 \rightarrow 3)$ branches. This data is consistent with others' data and reconfirms the special chemical structure of Weissella EPS (dextran) which shows high linearity with long chains and low branching $[56,60]$. The highly linear dextran from $W$. confusa VP30 could be used as a food modifier for thickening, viscosifying and also as a potential soluble fiber which can act as a prebiotic [61].

\section{Safety evaluation}

Multiple Weissella strains have been detected and screened from traditional fermented foods as naturally occurring microbiota. Specifically, W. viridescens, W. confusa and W. cibaria were extracted from fermented vegetables [62-64] (e.g. kimchi and sauerkraut); from fermented meat products $[65,66]$ (i.e. Italian fermented sausages and Greek dry salami), W. hellinica, W. paramesenteroides, W. viridescens, W. paramesenteroides, W. minor and $W$. halotolerans were isolated. W. hellenica, $W$. halotolerans and W. viridescens were identified from fermented dairy product [67-69] (e.g. Romanian, mozzarella and cheddar cheeses).

Many research groups are trying to identify the biofunctional activities of Weissella spp. and practically apply them to food, feed, and/or cosmetic products as a starter cultures and/or additives [70-73]. Recently, Lee et al. [74] proposed two $W$. confusa spp. (i.e. $W$. confusa 20 and 31) screened from human fecal samples as potential probiotic bacteria due to their high antibiotic sensitivity and cell adhesion properties. W. kimchii PL9023 was isolated from the vagina of a healthy premenopausal woman and has been proposed as a potential probiotic bacteria due to its inhibitory effects on fungal and

Table 3 Assignment of ${ }^{1} \mathrm{H} /{ }^{13} \mathrm{C}$ chemical shift of dextran from $W$. confusa VP30 correlated with dextran from Netsopa et al. [56]

\begin{tabular}{|c|c|c|c|c|c|c|}
\hline Atom position & 1 & 2 & 3 & 4 & 5 & 6 \\
\hline \multicolumn{7}{|c|}{ W. confusa R003 [56] } \\
\hline${ }^{1} \mathrm{H}$ & 4.98 & 3.58 & 3.72 & 3.52 & 3.9 & $3.76 / 3.98$ \\
\hline${ }^{13} \mathrm{C}$ & 100.28 & 74.1 & 76.09 & 72.28 & 72.88 & 68.33 \\
\hline \multicolumn{7}{|l|}{ W. confusa VP30 } \\
\hline${ }^{1} \mathrm{H}$ & 4.99 & 3.59 & 3.72 & 3.54 & 3.91 & $3.77 / 3.99$ \\
\hline${ }^{13} \mathrm{C}$ & 100.57 & 74.26 & 76.26 & 72.39 & 73.04 & 68.39 \\
\hline
\end{tabular}


bacterial vagina infection by Candida albicans, Escherichia coli, Staphylococcus aureus and Streptococcus agalactiae [75]. Fusco et al. [76] reported six types of bacteriocin-producing Weissella spp. (i.e. W. paramesenteroides, W. hellenica, and W. cibarian). Recently, Kang et al. [77] practically applied W. cibaria to chewing gum and evaluated cell survival rates with changed environmental factors (e.g. temperature and additives). Zannini et al. [78] applied W. cibaria MG1 isolated from cereal to wort (beer substrate) production. Recently Abriouel et al. [79] published reviews of anti-viral, anti-tumoral, antiobesity, anti-inflammatory, and antioxidant activities of Weissella and suggested the possibility of their use as a starter culture.

Although the superior functionality and universality of the Weissella spp. in fermented foods is of interest within academia, several studies have also warned of the possibility for side effects (e.g. hemolytic activity, production of toxic substances during ammonia metabolism, and antibiotic resistance by their host). Recently, Abriouel et al. [79] conducted in silico gene expression analysis with several Weissella spp. and reported the presence of antibiotics (e.g. daunorubicin, fosfomycin, methicillin and tetracycline) resistance, hemolysin gene in these microorganisms. Jung and Lee [80] evaluated the antibiotic resistance, hemolysis and biogenic amine production properties of 45 Weissella strains (i.e. W. cibaria $[\mathrm{n}=33$ ], $W$. confusa $[\mathrm{n}=11]$ and $W$. paramesenteroides $[\mathrm{n}=1])$ isolated from kimchi for kimchi starter development. They reported that all Weissella strains $(n=45)$ showed significant antibiotic resistance against streptomycin when the disk diffusion test was applied. Specifically,
$54.5 \%$ of tested W. cibaria $(\mathrm{n}=18)$ was resistant to gentamicin, and $15.2 \%$ to penicillin $G(n=5) .8 .5 \%$ of $W$. confusa was resistant to gentamicin $(\mathrm{n}=3)$. In their study, only one species of $W$. paramesenteroides $(n=1)$ was used, and this strain showed antibiotic resistance against gentamicin. In addition, some $\mathrm{LAB}$ are known to produce ammonia, which is generally regarded as a toxic substance produced by edible microorganisms via utilization of nitrogen sources during fermentation [81, 82]. Therefore, safety evaluation is critically required for further industrial applications even though $W$. confusa VP30 has been isolated from the feces of healthy children.

Listeria ivanovii subsp. ivanovii ATCC 19119 and W. confusa VP30 were streaked on BHI with 1.5\% agar and $5 \%$ horse blood and incubated at $37{ }^{\circ} \mathrm{C}$ for $48 \mathrm{~h}$. The microorganisms that produced clear and/or transparent zones around the cell colonies were classified as $\beta$-hemolytic. Microorganisms that did not generate any visual changes on the blood agar were regarded non hemolytic cell. Figure 4 shows significant transparent and clean zones around the $\beta$-hemolytic positive control Listeria ivanovii subsp. ivanovii ATCC 19119, due to the complete lysis of red blood cells on the media. Other strains belonging to the Weissella confusa species have been reported as alpha- hemolytic [83]. However, W. confusa VP30 generated no clear or transparent zones on the blood agar around their microbial colonies, indicating that $W$. confusa VP30 is non-hemolytic (a.k.a. $\gamma$-hemolytic).

LAB's ammonia production property can potentially be related to host gastrointestinal health. Some researchers have reported ammonia production properties of
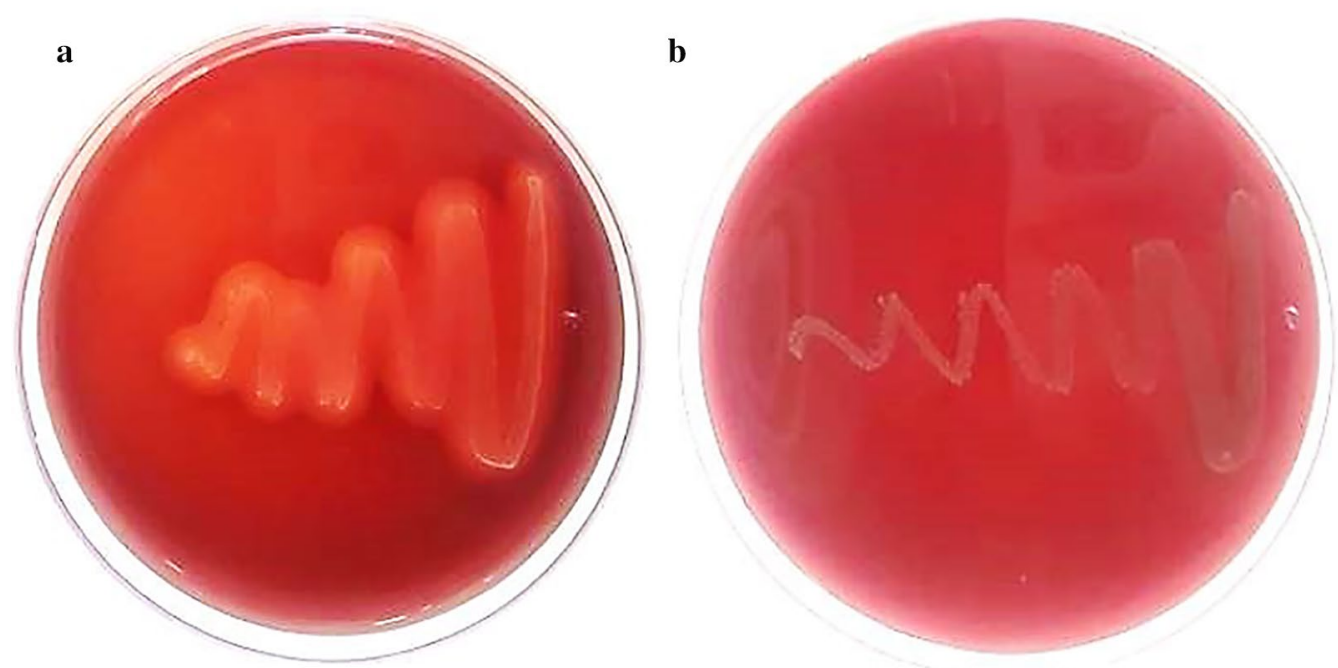

Fig. 4 a Comprehensive lysis of red blood cells was observed with clear zones around the Listeria ivanovii subsp. ivanovii ATCC 19119 (positive control). b W. confusa VP30 growth with no blood cell lysis on the blood agar. The hemolytic activity of each strain was assessed in triplicate 
Lactobacillus spp. [82, 84]. Therefore it is necessary to evaluate W. confusa VP30's ammonia production capability and demonstrate its safety for further application in processed food production [25]. A colorimetric assay was used to assess the level of ammonia in the media after incubation. Enterobacter cloacae KCTC 2361, the positive control for ammonia production, produced $11.5 \pm 0.9 \mu \mathrm{g} / \mathrm{ml}$ of ammonia while $W$. confusa VP30 was negative.

Excessive use of antibiotics has been reported to contribute to increasing numbers of pathogens having antibiotic resistance, which is considered a serious threat to the treatment of bacterial infection. Although many LAB are not commonly regarded as pathogenic bacteria, it is desirable that they be sensitive to commercially available antibiotics at low concentrations. To evaluate the antimicrobial resistance properties of $W$. confusa VP30, we conducted MIC tests based on the International Organization for Standardization (ISO) standard protocol. Based on the MIC criteria for microorganisms used in food or feeds prescribed in EFSA [85], W. confusa VP30 was found to have no significant resistance to gentamicin, kanamycin, streptomycin, tetracycline, clindamycin, ampicillin $(<4 \mu \mathrm{g} / \mathrm{ml}$, Table 4$)$. Although there are no reference concentration and/or guidelines for methicillin, dicloxacillin hydrate, polymyxin B sulfate, bacitracin, neomycin, carbenicillin and spectinomycin resistance, $W$. confusa VP30 was found to be sensitive to these antibiotics as well, with MIC values ranging from 1 to $32 \mu \mathrm{g} /$ $\mathrm{ml}$. On the other hand, W. confusa VP30 was resistant to erythromycin and chloramphenicol. (MIC ranging from 2 to $8 \mu \mathrm{g} / \mathrm{ml}$ ). Compared with other W. confusa strains [86, 87], Lactobacillus plantarum ATCC 14917 [37] and Lactobacillus paracasei ATCC334 [37], W. confusa VP30 have similar or lower MIC concentrations of gentamicin, kanamycin, tetracycline, clindamycin, ampicillin and erythromycin.

\section{Conclusion}

The objective of this work was to screen and characterize high level EPS-producing LAB from healthy children's feces for potential functional food applications. As a prescreening process, 156 LAB cell strains were screened and isolated using $\mathrm{LAB}$ selective media (i.e. LBS and TOS-MUP) and cultivated in eight different modified MRS broths containing various sugars. When the $156 \mathrm{LAB}$ strains were cultivated in media supplemented with sucrose as the major carbon source, the viscosity of microbial colonies was increased. The 10 most mucoid and slimy colony-producing colonies

Table 4 MIC distributions of seventeen antibiotics for W. confusa VP30 isolates from a child fecal sample determined by the ISO 10932:2010 broth microdilution procedure

\begin{tabular}{|c|c|c|c|c|c|c|}
\hline & $\begin{array}{l}\text { Weissella } \\
\text { confusa VP30 } \\
\text { ( } \mu \mathrm{g} / \mathrm{ml})\end{array}$ & $\begin{array}{l}\text { Weissella } \\
\text { confusa }[87] \\
(\mu \mathrm{g} / \mathrm{ml})\end{array}$ & $\begin{array}{l}\text { Weissella } \\
\text { confusa }[86] \\
(\mu \mathrm{g} / \mathrm{ml})\end{array}$ & $\begin{array}{l}\text { Lactobacillus } \\
\text { paracasei ATCC334 } \\
{[37](\mu \mathrm{g} / \mathrm{ml})}\end{array}$ & $\begin{array}{l}\text { Lactobacillus } \\
\text { plantarum } \\
\text { ATCC14917 [37] }(\mu \mathrm{g} / \\
\mathrm{ml})\end{array}$ & $\begin{array}{l}\text { EFSA cut-off } \\
\text { of Leuconostoc [85] } \\
(\mu \mathrm{g} / \mathrm{ml})\end{array}$ \\
\hline Gentamicin & 1 & $\leq 2$ & 3 & 1 to 4 & - & 16 \\
\hline Kanamycin & 4 & - & - & 16 to 64 & - & 16 \\
\hline Vancomycin & $>128$ & Resistant & $>256$ & - & - & $\mathrm{nr}$ \\
\hline Streptomycin & 32 & - & - & 8 to 12 & - & 64 \\
\hline Tetracycline & 2 & 4 to 8 & - & 1 to 4 & 8 to 32 & 8 \\
\hline Clindamycin & $<0.032$ & $\leq 0.5$ & 0.06 & 0.06 to 0.25 & 0.5 to 4 & 1 \\
\hline Ampicillin & 0.5 & 0.5 & 0.5 & 0.5 to 2 & 0.25 to 2 & 2 \\
\hline Erythromycin & 2 & $\leq 0.25$ & 0.13 & 0.06 to 0.5 & 0.25 to 2 & 1 \\
\hline Methicillin & 32 & - & - & - & - & - \\
\hline $\begin{array}{l}\text { Dicloxacillin salt } \\
\text { hydrate }\end{array}$ & 8 & - & - & - & - & - \\
\hline Polymycin B sulfate salt & 32 & - & - & - & - & - \\
\hline Bacitracin & 1 & - & - & - & - & - \\
\hline Methronidazole & 512 & & $>256$ & - & - & - \\
\hline $\begin{array}{l}\text { Phosphomycin diso- } \\
\text { dium salt }\end{array}$ & $>1024$ & & - & - & - & - \\
\hline Neomycin & 2 & - & - & - & - & - \\
\hline Carbenicillin & 2 & - & - & - & - & - \\
\hline Chloramphenicol & 8 & 8 & - & 2 to 8 & 4 to 16 & 4 \\
\hline Spectinomycin & 32 & - & - & - & - & - \\
\hline
\end{tabular}


were selected based on their solid agar media phenotypes as EPS positive strains. 16S rRNA gene sequencing analysis showed that these high EPS-producing cell strains were members of Weissella confusa, Bifidobacterium longum, Lactobacillus plantarum, Lactobacillus fermentum, Lactobacillus paracasei and Lactobacillus rhamnosus genus and species. Among them, W. confusa VP30 showed significantly higher EPS productivity compared to the other cell strains and was selected for further testing. The maximum EPS production by W. confusa VP30 was $59.99 \pm 0.91 \mathrm{~g} / \mathrm{l}$. Structural analysis of the released EPS fraction by NMR revealed that W. confusa VP30 can produce dextran of $3.8 \times 10^{6} \mathrm{Da}$, containing glucose units linked with $96.5 \% \alpha(1 \rightarrow 6)$ glycosidic bonds and 3.5\% $\alpha(1 \rightarrow 3)$ branches. Safety assessment of $W$. confusa VP30 was accomplished via ammonia production, hemolysis of blood cells and antibiotic resistance analyses. There is no evidence that this LAB strain is unsafe for human consumption, based on our results. Considering the active EPS producing capability and safety of W. confusa VP30, this microbial cell strain can be considered for use by the food industry.

\section{Acknowledgements}

The authors thank Mrs. Fushi Piao for assistance with fecal sample collection and National Instrumentation Center for Environmental Management (NICEM) at Seoul National University for assistance with HPLC, GPC, NMR and SEM analysis.

\section{Authors' contributions \\ $\mathrm{HJ}$ initiated this work in partial fulfillment of her Ph.D. degree at Seoul National University under the supervision of SK and GEJ. HJ performed most experi- ments under the mentorship of S-HY, SK and GEJ. HJ, YJ and S-HY analyzed data. HJ, YJ, SK and TVJ collaboratively wrote the manuscript and performed the literature review. All authors discussed the drafts. All authors read and approved the final manuscript.}

\section{Funding}

This work was carried out with support from the National Research Foundation of Korea (NRF) Grant (No. 2017R1A2B2012390) funded by the Korea government (MSIP), High Value-added Food Technology Development Program (No. 317043-3), Korea Institute of Planning and Evaluation for Technology in Food, Agriculture, Forestry and Fisheries (IPET), Ministry of Agriculture, Food and Rural Affairs (MAFRA), and the Technological Innovation R\&D Program (No. S2463318) funded by the Small and Medium Business Administration, Republic of Korea, and the Faculty Research and Creative Activity Committee (FRCAC) Grant (No. 221745) funded by Middle Tennessee State University (MTSU).

\section{Availability of data and materials}

The datasets used and/or analysed during the current study are available from the corresponding author on reasonable request.

\section{Ethics approval and consent to participate}

Not applicable.

\section{Consent for publication}

Not applicable.

\section{Competing interests}

The authors declare that they have no competing interests.

\section{Author details}

${ }^{1}$ Department of Food and Nutrition, Research Institute of Human Ecology, Seoul National University, Seoul 08826, South Korea. ${ }^{2}$ Research Center, BIFIDO Co., Ltd., Hongcheon 25117, South Korea. ${ }^{3}$ Department of Food Science \& Biotechnology, and Carbohydrate Bioproduct Research Center, Sejong University, Seoul 143-747, South Korea. ${ }^{4}$ Fermentation Science Program, School of Agriculture, College of Basic and Applied Sciences, Middle Tennessee State University, Murfreesboro, TN 37132, USA.

Received: 23 April 2019 Accepted: 8 June 2019

Published online: 13 June 2019

\section{References}

1. Saranraj P, Naidu M, Sivasakthivelan P. Lactic acid bacteria and its antimicrobial properties: a review. Int J Pharm Biol Arch. 2013;4:1124-33.

2. Muyanja C, Narvhus JA, Treimo J, Langsrud T. Isolation, characterisation and identification of lactic acid bacteria from bushera: a Ugandan traditional fermented beverage. Int J Food Microbiol. 2003;80:201-10.

3. Ring $\varnothing$, Gatesoupe F-J. Lactic acid bacteria in fish: a review. Aquaculture. 1998;160:177-203.

4. Moreno-Arribas MV, Polo MC, Jorganes F, Muñoz R. Screening of biogenic amine production by lactic acid bacteria isolated from grape must and wine. Int J Food Microbiol. 2003;84:117-23.

5. Toghyani M, Toghyani M, Tabeidian SA. Effect of probiotic and prebiotic as antibiotic growth promoter substitutions on productive and carcass traits of broiler chicks. In: International conference on food engineering and biotechnology IPCBEE. 2011. p. 82-6.

6. Zoumpopoulou G, Kazou M, Alexandraki V, Angelopoulou A, Papadimitriou K, Pot B, Tsakalidou E. Probiotics and prebiotics: an overview on recent trends. Probiotics and prebiotics in animal health and food safety. Berlin: Springer; 2018. p. 1-34.

7. Global Market Insights. https://www.gminsights.com/industry-analysis/ probiotics-market. Accessed 6 Mar 2019

8. Ku S, Park M, Ji G, You H. Review on bifidobacterium bifidum bgn4: functionality and nutraceutical applications as a probiotic microorganism. Int J Mol Sci. 2016;17:1544

9. Ku S, You HJ, Ji GE. Enhancement of anti-tumorigenic polysaccharide production, adhesion, and branch formation of Bifidobacterium bifidum BGN4 by phytic acid. Food Sci Biotechnol. 2009;18:749-54.

10. Ai C, Ma N, Zhang Q, Wang G, Liu X, Tian F, Chen P, Chen W. Immunomodulatory effects of different lactic acid bacteria on allergic response and its relationship with in vitro properties. PLoS ONE. 2016;11:e0164697.

11. Kaur R, Kumar Tiwari S. Optimization of culture conditions for bacteriocin production by soil isolates Pediococcus pentosaceus LB44 and Weissella confusa LM85. Int J Infect. 2017:4:e15842.

12. Uraipan S, Hongpattarakere T. Antagonistic characteristics against food-borne pathogenic bacteria of lactic acid bacteria and bifidobacteria isolated from feces of healthy thai infants. Jundishapur J Microbiol. 2015;8:e18264.

13. Yoon JS, Sohn W, Lee OY, Lee SP, Lee KN, Jun DW, Lee HL, Yoon BC, Choi HS, Chung WS. Effect of multispecies probiotics on irritable bowel syndrome: a randomized, double-blind, placebo-controlled trial. J Gastroenterol Hepatol. 2014;29:52-9.

14. Riezzo G, Orlando A, D'Attoma B, Guerra V, Valerio F, Lavermicocca P, De Candia S, Russo F. Randomised clinical trial: efficacy of Lactobacillus paracasei-enriched artichokes in the treatment of patients with functional constipation-a double-blind, controlled, crossover study. Alim Pharmacol Ther. 2012;35:441-50.

15. Jia W, Li H, Zhao L, Nicholson JK. Gut microbiota: a potential new territory for drug targeting. Nat Rev Drug Dis. 2008;7:123.

16. Krivoruchko A, Zhang Y, Siewers $V$, Chen Y, Nielsen J. Microbial acetyl-CoA metabolism and metabolic engineering. Metab Eng. 2015;28:28-42.

17. Meadow JF, Altrichter AE, Bateman AC, Stenson J, Brown GZ, Green JL, Bohannan BJM. Humans differ in their personal microbial cloud. PeerJ. 2015;3:e1258.

18. Rühmann B, Schmid J, Sieber V. High throughput exopolysaccharide screening platform: from strain cultivation to monosaccharide composition and carbohydrate fingerprinting in one day. Carbohyd Polym. 2015;122:212-20. 
19. Patel AK, Michaud P, Singhania RR, Soccol CR, Pandey A. Polysaccharides from probiotics: new developments as food additives. Food Technology and Biotechnology. 2010;48:451-63.

20. Nowak B, Ciszek-Lenda M, Śróttek M, Gamian A, Kontny E, Górska-Frączek S, Marcinkiewicz J. Lactobacillus rhamnosus exopolysaccharide ameliorates arthritis induced by the systemic injection of collagen and lipopolysaccharide in DBA/1 mice. Arch Immunol Ther Exp. 2012;60:211-20.

21. London LEE, Kumar AHS, Wall R, Casey PG, O'Sullivan O, Shanahan F, Hill C, Cotter PD, Fitzgerald GF, Ross RP, et al. Exopolysaccharide-producing probiotic lactobacilli reduce serum cholesterol and modify enteric microbiota in apoE-deficient mice. J Nutr. 2014;144:1956-62.

22. Del Piano M, Balzarini M, Carmagnola S, Pagliarulo M, Tari R, Nicola S, Deidda F, Pane M. Assessment of the capability of a gelling complex made of tara gum and the exopolysaccharides produced by the microorganism Streptococcus thermophilus ST10 to prospectively restore the gut physiological barrier: a pilot study. J Clin Gastroenterol. 2014;48:S56-61.

23. Adesulu-Dahunsi AT, Sanni Al, Jeyaram K. Production, characterization and in vitro antioxidant activities of exopolysaccharide from Weissella cibaria GA44. Lwt-Food Sci Technol. 2018;87:432-42.

24. Sanalibaba P, Çakmak GA. Exopolysaccharides production by lactic acid bacteria. Appl Microbiol Open Access. 2016;2:115.

25. Kim MJ, Ku S, Kim SY, Lee HH, Jin H, Kang S, Li R, Johnston TV, Park MS, Ji GE. Safety evaluations of Bifidobacterium bifidum BGN4 and Bifidobacterium longum BORI. Int J Mol Sci. 2018;19:1422.

26. Ku S, Zheng H, Park MS, Ji GE. Optimization of $\beta$-glucuronidase activity from Lactobacillus delbrueckii Rh2 and its use for biotransformation of baicalin and wogonoside. J Korean Soc Appl Biol Chem. 2011;54:275-80.

27. McCoy S, Gilliland S. Isolation and characterization of Lactobacillus species having potential for use as probiotic cultures for dogs. J Food Sci. 2007;72:M94-7.

28. Coeuret V, Dubernet S, Bernardeau M, Gueguen M, Vernoux JP. Isolation, characterisation and identification of lactobacilli focusing mainly on cheeses and other dairy products. Le Lait. 2003;83:269-306.

29. Süle J, Kõrösi T, Hucker A, Varga L. Evaluation of culture media for selective enumeration of bifidobacteria and lactic acid bacteria. Braz J Microbiol. 2014:45:1023-30.

30. Gorissen L, Raes K, De Smet S, De Vuyst L, Leroy F. Microbial production of conjugated linoleic and linolenic acids in fermented foods: technological bottlenecks. Eur J Lipid Sci Technol. 2012;114:486-91.

31. Ku S, You HJ, Park MS, Ji GE. Whole-cell biocatalysis for producing ginsenoside Rd from Rb1 using Lactobacillus rhamnosus GG. J Microbiol Biotechnol. 2016;26:1206-15.

32. Ku S, You HJ, Park MS, Ji GE. Effects of ascorbic acid on a-Larabinofuranosidase and a-L-arabinopyranosidase activities from Bifidobacterium longum RD47 and its application to whole cell bioconversion of ginsenoside. J Korean Soc Appl Biol Chem. 2015;58:857-65.

33. Ruas-Madiedo P, De Los Reyes-Gavilán C. Invited review: methods for the screening, isolation, and characterization of exopolysaccharides produced by lactic acid bacteria. J Dairy Sci. 2005;88:843-56.

34. Srinivasan S, Lim S, Lim J-H, Jung H-Y, Kim MK. Deinococcus rubrus sp. Nov., a bacterium isolated from Antarctic coastal sea water. J Microbiol Biotechnol. 2017;27:535-41.

35. Mendi A, Aslım B. Antioxidant lactobacilli could protect gingival fibroblasts against hydrogen peroxide: a preliminary in vitro study. Probiot Antimicrob Proteins. 2014;6:157-64.

36. Shin YS, Park SD, Kim JH. Influence of pollination methods on fruit development and sugar contents of oriental melon (Cucumis melo L. CV. Sagyejeol-Ggul). Sci Horticult. 2007;112:388-92.

37. International Organization for S. Milk and milk products: determination of the minimal inhibitory concentration (MIC) of antibiotics applicable to bifidobacteria and non-enterococcal lactic acid bacteria. Geneva: International Organization for Standardization; International Dairy Federation; 2010.

38. Rühmann B, Schmid J, Sieber V. Methods to identify the unexplored diversity of microbial exopolysaccharides. Front Microbiol. 2015;6:565.

39. Maalej H, Hmidet N, Boisset C, Buon L, Heyraud A, Nasri M. Optimization of exopolysaccharide production from Pseudomonas stutzeri AS22 and examination of its metal-binding abilities. J Appl Microbiol. 2015;118:356-67.

40. Collins M, Samelis J, Metaxopoulos J, Wallbanks S. Taxonomic studies on some Leuconostoc-like organisms from fermented sausages: description of a new genus Weissella for the Leuconostoc paramesenteroides group of species. J Appl Bacteriol. 1993;75:595-603.

41. Stiles ME, Holzapfel WH. Lactic acid bacteria of foods and their current taxonomy. Int J Food Microbiol. 1997;36:1-29.

42. Han J, Xu X, Gao C, Liu Z, Wu Z. Levan-producing "named-content genusspecies" Leuconostoc citreum strain BD1707 and its growth in tomato juice supplemented with sucrose. Appl Environ Microbiol. 2016;82:1383-90.

43. Meng X, Dobruchowska JM, Pijning T, Gerwig GJ, Dijkhuizen L. Synthesis of new hyperbranched a-glucans from sucrose by Lactobacillus reuteri 180 glucansucrase mutants. J Agric Food Chem. 2016;64:433-42.

44. Bae JT, Sim GS, Lee DH, Lee BC, Pyo HB, Choe TB, Yun JW. Production of exopolysaccharide from mycelial culture of Grifola frondosa and its inhibitory effect on matrix metalloproteinase-1 expression in UV-irradiated human dermal fibroblasts. FEMS Microbiol Lett. 2005;251:347-54.

45. Vasanthakumari DS, Harikumar S, Beena DJ, Pandey A, Nampoothiri KM. Physicochemical characterization of an exopolysaccharide produced by a newly isolated Weissella cibaria. Appl Biochem Biotechnol. 2015;176:440-53.

46. Di Cagno R, De Angelis M, Limitone A, Minervini F, Carnevali P, Corsetti A, Gaenzle M, Ciati R, Gobbetti M. Glucan and fructan production by sourdough Weissella cibaria and Lactobacillus plantarum. J Agric Food Chem. 2006:54:9873-81.

47. Yu Y-J, Chen Z, Chen PT, Ng IS. Production, characterization and antibacterial activity of exopolysaccharide from a newly isolated Weissella cibaria under sucrose effect. J Biosci Bioeng. 2018;126:769-77.

48. Wongsuphachat W, Maneerat S. Optimization of exopolysaccharides production by Weissella confusa NH 02 isolated from Thai fermented sausages. Songklanakarin J Sci Technol. 2010;32:27.

49. Kim MJ, Seo HN, Hwang TS, Lee SH, Park DH. Characterization of exopolysaccharide (EPS) produced by Weissella hellenica SKkimchi3 isolated from kimchi. J Microbiol. 2008:46:535-41.

50. Adesulu-Dahunsi AT, Sanni Al, Jeyaram K, Ojediran JO, Ogunsakin AO, Banwo K. Extracellular polysaccharide from Weissella confusa OF126: production, optimization, and characterization. Int J Biol Macromol. 2018;111:514-25.

51. Feng F, Zhou QQ, Yang YF, Zhao FK, Du RP, Han Y, Xiao HZ, Zhou ZJ. Characterization of highly branched dextran produced by Leuconostoc citreum B-2 from pineapple fermented product. Int J Biol Macromol. 2018;113:45-50.

52. Grosu-Tudor SS, Stancu MM, Stefan IR, Cornea CP, Zamfir M. Physicochemical and rheological properties of some exopolysaccharides produced by lactic acid bacteria isolated from plant origin materials. Roman Biotechnol Lett. 2017;22:12694-705.

53. Ahmed RZ, Siddiqui K, Arman M, Ahmed N. Characterization of high molecular weight dextran produced by Weissella cibaria CMGDEX3. Carbohyd Polym. 2012;90:441-6.

54. Sidebotham RL. Dextrans. Advances in carbohydrate chemistry and biochemistry, vol. 30. New York: Elsevier; 1974. p. 371-444.

55. Bounaix M-S, Gabriel V, Morel S, Robert H, Rabier P, Remaud-Simeon M, Gabriel B, Fontagne-Faucher C. Biodiversity of exopolysaccharides produced from sucrose by sourdough lactic acid bacteria. J Agric Food Chem. 2009;57:10889-97.

56. Netsopa S, Niamsanit S, Sakloetsakun D, Milintawisamai N. Characterization and rheological behavior of dextran from Weissella confusa R003. Int J Polym Sci. 2018;2018:10

57. Huang S-q, Li J-w, Li Y-q, Wang Z. Purification and structural characterization of a new water-soluble neutral polysaccharide GLP-F1-1 from Ganoderma lucidum. Int J Biol Macromol. 2011;48:165-9.

58. Maina NH, Tenkanen M, Maaheimo H, Juvonen R, Virkki L. NMR spectroscopic analysis of exopolysaccharides produced by Leuconostoc citreum and Weissella confusa. Carbohyd Res. 2008;343:1446-55.

59. Uzochukwu S, Balogh E, Loefler RT, Ngoddy PO. Structural analysis by 13C-nuclear magnetic resonance spectroscopy of glucans elaborated by gum-producing bacteria isolated from palm wine. Food Chem. 2001;73:225-33.

60. Yang YF, Feng F, Zhou QQ, Zhao FK, Du RP, Zhou ZJ, Han Y. Isolation, purification and characterization of exopolysaccharide produced by Leuconostoc pseudomesenteroides YF32 from soybean paste. Int J Biol Macromol. 2018;114:529-35. 
61. Kothari D, Tingirikari JMR, Goyal A. In vitro analysis of dextran from Leuconostoc mesenteroides NRRL B-1426 for functional food application. Bioactive Carbohydr Dietary Fibre. 2015;6:55-61.

62. Yang J, Ji Y, Park H, Lee J, Park S, Yeo S, Shin H, Holzapfel WH. Selection of functional lactic acid bacteria as starter cultures for the fermentation of Korean leek (Allium tuberosum Rottler ex Sprengel). Int J Food Microbiol. 2014;191:164-71.

63. Lee J-S, Lee KC, Ahn J-S, Mheen T-I, Pyun Y-R, Park Y-H. Weissella koreensis sp. nov., isolated from kimchi. Int J Syst Evol Microbiol. 2002:52:1257-61.

64. Plengvidhya V, Breidt F, Lu Z, Fleming HP. DNA fingerprinting of lactic acid bacteria in sauerkraut fermentations. Appl Environ Microbiol. 2007;73:7697-702.

65. Parente E, Grieco S, Crudele M. Phenotypic diversity of lactic acid bacteria isolated from fermented sausages produced in Basilicata (Southern Italy). J Appl Microbiol. 2001;90:943-52.

66. Kameník J, Dušková M, Šedo O, Saláková A, Pavlík Z, Zdráhal Z, Karpišková R. Lactic acid bacteria in hot smoked dry sausage (non-fermented salami): thermal resistance of Weissella viridescens strains isolated from hot smoked dry sausages. LWT-Food Sci Technol. 2015;61:492-5.

67. Morea M, Baruzzi F, Cappa F, Cocconcelli P. Molecular characterization of the Lactobacillus community in traditional processing of Mozzarella cheese. Int J Food Microbiol. 1998;43:53-60.

68. Zamfir M, Vancanneyt M, Makras L, Vaningelgem F, Lefebvre K, Pot B, Swings J, De Vuyst L. Biodiversity of lactic acid bacteria in Romanian dairy products. Syst Appl Microbiol. 2006;29:487-95.

69. Williams AG, Banks JM. Proteolytic and other hydrolytic enzyme activities in non-starter lactic acid bacteria (NSLAB) isolated from Cheddar cheese manufactured in the United Kingdom. Int Dairy J. 1997;7:763-74.

70. Choi H, Kim Y-W, Hwang I, Kim J, Yoon S. Evaluation of Leuconostoc citreum $\mathrm{HO} 12$ and Weissella koreensis $\mathrm{HO} 20$ isolated from kimchi as a starter culture for whole wheat sourdough. Food Chem. 2012;134:2208-16.

71. Di Cagno R, Surico RF, Minervini G, De Angelis M, Rizzello CG, Gobbetti M. Use of autochthonous starters to ferment red and yellow peppers (Capsicum annum L.) to be stored at room temperature. Int J Food Microbiol. 2009;130:108-16.

72. Wolter A, Hager A-S, Zannini E, Galle S, Gänzle M, Waters DM, Arendt EK. Evaluation of exopolysaccharide producing Weissella cibaria MG1 strain for the production of sourdough from various flours. Food Microbiol. 2014;37:44-50.

73. Robert H, Gabriel V, Lefebvre D, Rabier P, Vayssier Y, Fontagné-Faucher C. Study of the behaviour of Lactobacillus plantarum and Leuconostoc starters during a complete wheat sourdough breadmaking process. LWTFood Sci Technol. 2006;39:256-65.

74. Lee KW, Park JY, Jeong HR, Heo HJ, Han NS, Kim JH. Probiotic properties of Weissella strains isolated from human faeces. Anaerobe. 2012;18:96-102.

75. Lee Y. Characterization of Weissella kimchii PL9023 as a potential probiotic for women. FEMS Microbiol Lett. 2005;250:157-62.

76. Fusco V, Quero GM, Cho G-S, Kabisch J, Meske D, Neve H, Bockelmann W, Franz CM. The genus Weissella: taxonomy, ecology and biotechnological potential. Front Microbiol. 2015;6:155.

77. Kang MS, Kim YS, Lee HC, Lim HS, Oh JS. Comparison of temperature and additives affecting the stability of the probiotic Weissella cibaria. Chonnam Med J. 2012:48:159-63.
78. Zannini E, Mauch A, Galle S, Gänzle M, Coffey A, Arendt EK, Taylor JP, Waters DM. Barley malt wort fermentation by exopolysaccharide-forming Weissella cibaria MG1 for the production of a novel beverage. J Appl Microbiol. 2013;115:1379-87.

79. Abriouel H, Lerma LL, Casado Muñoz MC, Montoro BP, Kabisch J, Pichner R, Cho G-S, Neve H, Fusco V, Franz CMAP, et al. The controversial nature of the Weissella genus: technological and functional aspects versus whole genome analysis-based pathogenic potential for their application in food and health. Front Microbiol. 2015;6:38.

80. Jeong D-W, Lee J-H. Antibiotic resistance, hemolysis and biogenic amine production assessments of Leuconostoc and Weissella isolates for kimchi starter development. LWT Food Sci Technol. 2015;64:1078-84.

81. Sánchez I, Palop L, Ballesteros C. Biochemical characterization of lactic acid bacteria isolated from spontaneous fermentation of 'Almagro' eggplants. Int J Food Microbiol. 2000;59:9-17.

82. Saarisalo E, Skyttä E, Haikara A, Jalava T, Jaakkola S. Screening and selection of lactic acid bacteria strains suitable for ensiling grass. J Appl Microbiol. 2007;102:327-36.

83. Lee W, Cho S-M, Kim M, Ko Y-G, Yong D, Lee K. Weissella confusa bacteremia in an immune-competent patient with underlying intramural hematomas of the aorta. Ann Lab Med. 2013;33:459-62.

84. Vince AJ, Burridge SM. Ammonia production by intestinal bacteria: the effects of lactose, lactulose and glucose. J Med Microbiol. 1980;13:177-91.

85. Additives EPo, Feed PoSuiA. Guidance on the assessment of bacterial susceptibility to antimicrobials of human and veterinary importance. EFSA J. 2012;10:2740.

86. Švec P, Ševčíková A, Sedláček I, Bednářová J, Snauwaert C, Lefebvre K, Vandamme $\mathrm{P}$, Vancanneyt M. Identification of lactic acid bacteria isolated from human blood cultures. FEMS Immunol Med Microbiol. 2007:49:192-6.

87. Medford R, Patel SN, Evans GA. A confusing case-Weissella confusa prosthetic joint infection: a case report and review of the literature. Can J Infect Dis Med Microbiol. 2014;25:173-5.

88. Kavitake D, Devi PB, Singh SP, Shetty PH. Characterization of a novel galactan produced by Weissella confusa KR780676 from an acidic fermented food. Int J Biol Macromol. 2016;86:681-9.

89. DuBois M, Gilles KA, Hamilton JK, Rebers PA, Smith F. Colorimetric method for determination of sugars and related substances. Anal Chem. 1956:28:350-6.

90. Rosca I, Petrovici AR, Peptanariu D, Nicolescu A, Dodi G, Avadanei M, Ivanov IC, Bostanaru AC, Mares M, Ciolacu D. Biosynthesis of dextran by Weissella confusa and its in vitro functional characteristics. Int J Biol Macromol. 2018;107:1765-72.

91. Tayuan C, Tannock GW, Rodtong S. Growth and exopolysaccharide production by Weissella sp. from low-cost substitutes for sucrose. Afr J Microbiol Res. 2011:5:3693-701.

\section{Publisher's Note}

Springer Nature remains neutral with regard to jurisdictional claims in published maps and institutional affiliations.

Ready to submit your research? Choose BMC and benefit from

- fast, convenient online submission

- thorough peer review by experienced researchers in your field

- rapid publication on acceptance

- support for research data, including large and complex data types

- gold Open Access which fosters wider collaboration and increased citations

- maximum visibility for your research: over 100M website views per year

At BMC, research is always in progress.

Learn more biomedcentral.com/submissions 